\title{
CERITA SEBAGAI MEDIUM MEMBANGUN NILAI-NILAI KARAKTER DI SEKOLAH TK ANNIZOMIYAH PEJATEN JAKARTA
}

\author{
Dwi Kartikawati*1, Nurhasanah ${ }^{2}$ \\ ${ }^{1,2}$ Universitas Nasional Jakarta; Jalan Sawo Manila Pasar Minggu Jakarta, 021-7806700 \\ Program Studi Ilmu Komunikasi, Fakultas Ilmu Sosial dan Ilmu Politik Universitas Nasional \\ *E-mail: kartikapujisantoso@yahoo.co.id
}

\begin{abstract}
National character development has never been this urgent due to the rapid development of science and technology as well as globalization nowadays. This effort can be done through storytelling since it is an effective way of the instillation of morality and good character development for children of a young age. Storytelling activities in Annizomiyah Kindergarten in Pejaten, South Jakarta, aimed to encourage students to acquire, master and comprehend the noble values in the stories such as honesty, cooperation, etc. Storytelling was one among their other various learning tools in respect of developing national characters. In conclusion, interactive storytelling is an effective way to obtain the goals of this school in regards to the character development since noble values can easily be instilled in young children's mind through interesting and compelling stories so that they will grow as individuals with good moral characters in future.
\end{abstract}

Keywords-Storytelling, Character values, Kindergarten School

\begin{abstract}
Abstrak
Membangun nilai-nilai karakter yang baik menjadi sangat urgent untuk dikembangkan karena melihat kondisi perkembangan iptek dan globalisasi sekarang ini. Bercerita adalah cara yang efektif dalam menanamkan moral pada anak-anak dan membentuk nilai-nilai karakter yang baik Kegiatan bercerita ini diselenggarakan di sekolah Taman Kanak-Kanak Annizomiyah Pejaten Jakarta Selatan. Tujuannya adalah supaya para siswa TK dapat mengenal, menguasai dan memahami mengenai nilai-nilai karakter yang baik dalam cerita antara lain kejujuran, kerjasama, dan lain-lain. Bercerita dimanfaatkan sebagai sarana pembelajaran yang variatif dalam pendidikan karakter bangsa. Hasil evaluasi dari kegiatan pengabdian masyarakat ini adalah para siswa TK menunjukkan antusiasme tinggi, mampu berinteraksi dengan para pencerita, dan ketika dievaluasi nilai-nilai karakter yang baik dan buruk yang muncul dalam cerita mereka mampu memberikan contoh dalam kehidupan sehari hari mereka. Akhirnya, dengan penceritaan yang menarik maka tujuan kegiatan ini bisa dicapai karena para peserta bisa belajar dari cerita sehingga bisa menumbuhkan menjadi pribadi-pribadi yang berkarakter nantinya.
\end{abstract}

Kata kunci-Cerita, Nilai Karakter, Sekolah Taman Kanak-kanak

\section{PENDAHULUAN}

Pendidikan tidak hanya membangun kecerdasan intelektual seseorang semata tetapi juga perlu dikembangkan kemampuan antara lain terbentuknya watak atau karakter peserta didik yang baik. Dengan pendidikan karakter, bukan hanya mengajarkan benar dan salah, namun mencakup soal pembiasaan yang baik sehingga siswa dapat memahami dan berperilaku sesuai aturan. Karakter adalah sifat atau akhlak yang dimiliki setiap individu, yang terbentuk karena pembiasaanpembiasaan yang dilakukan oleh semua anggota keluarga di dalam keluarga dan di lingkungan sekitarnya. Usia dini adalah menjadi periode penting dalam pendidikan karakter seseorang. Perilaku dan kebiasaan yangbaik akan menjadi pembiasaan mereka sehari-hari pada akhirnya akan membudaya pada diri anak usia dini. Jika anak usia dini telah dibangun jiwanya secara sehat sesuai 
kondisi psikologisnya, maka akan berpengaruh dalam pengamalan karakter sepanjang hidupnya. Lingkungan sekolah pada hakikatnya bukan sekadar tempat transfer pengetahuan, melainkan juga mengupayakan usaha dan proses pembelajaran yang berorientasi pada nilai (Salahuddin \& Alkrienciehie, 2013:42). Kementerian Pendidikan Nasional (2011: 9) telah merumuskan 18 nilai karakter yang akan digunakan untuk membangun karakter melalui pendidikan. Kemudian disesuaikan dengan kaidah-kaidah ilmu pendidikan secara umum dan telah dirumuskan standar kompetensi dan indikator pencapaiannya di semua mata pelajaran. Delapan belas nilai tersebut adalah nilai religius, jujur, toleransi, disiplin, kerja keras, kreatif, mandiri, demokratis, rasa ingin tahu, semangat kebangsaan, cinta tanah, menghargai prestasi, bersahabat, cinta damai, gemar membaca, peduli lingkungan, peduli sosial, dan tanggung jawab. Pembentukan karakter yang baik tersebut menjadi sangat urgent untuk dikembangkan karena melihat kondisi perkembangan iptek dan globalisasi yang dampaknya sudah semakin menggeser nilai-nilai budaya adiluhung seperti menyanyi, bercerita, dan lain-lain, yang digantikan dengan perkembangan internet yang sangat massif termasuk bagi anak anak usia taman kanak-kanak. Usia taman kanak-kanak adalah termasuk dalam kategori usia dini. Karakteristik usia dini (Amini, M, 2014:1.4-1.9) adalah: (1) memiliki rasa ingin tahu yang besar, (2). Memiliki pribadi yang unik,(3). Suka berfantasi atau berimaginasi, (4). Masa paling memiliki potensi besar untuk belajar, (5). Menunjukkan sikap egosentris.(6). Memiliki rentang daya konsentrasi yang pendek. (7) sebagai bagian dari makhluk sosial.

Usia anak TK adalah usia untuk bermain sambil belajar dan belajar seraya bermain (Surat Edaran Mendikdasmen Depdiknas Nomor 1839/C.C2/TU/2009," n.d.). Maka bermain merupakan cara terbaik untuk mengembangkan potensi anak didik. Sebelum bersekolah, bermain merupakan cara alamiah untuk menemukan lingkungan, orang lain dan dirinya sendiri. Untuk itu supaya anakanak TK ini dapat menyerap apa yang diberikan, antara lain dengan pendekatan bermain. Sehingga dengan kegiatan bercerita diharapkan anak-anak TK ini menjadi tertarik. Usia anak di taman kanak-kanak memiliki imajinasi tinggi, sehingga strategi storytelling atau kegiatan bercerita dalam pembentukan karakter bangsa perlu dipertimbangkan. Storytelling atau bercerita adalah Bercerita adalah menuturkan sesuatu yang mengisahkan tentang perbuatan atau sesuatu kejadian dan disampaikan secara lisan dengan tujuan membagikan pengalaman dan pengetahuan kepada orang lain ( Khasinah,, 2006:100). Pada pendidikan usia kanak-kanak masih dalam rentang usia golden age, adalah rentang usia kritis sekaligus strategis dalam menumbuh kembangkan berbagai kemampuan, kecerdasan, bakat, kemampuan fisik, kognitif, bahasa, sosial, spiritual dan lain-lain. Maka dengan media Storytelling ini mendorong untuk menambah kemampuan mendengarkan, kemampuan komunikasi lisan sehingga menambah perbendaharan kata serta mengenal simbolsimbol sederhana dalam struktur penggunaan ide yang terwujud melalui bahasa.

Strategi storytelling, atau strategi bercerita (mendongeng) mampu membawa anak untuk berimajinasi dan berfantasi terhadap cerita yang dibawakannya sehingga anak mampu mengkreasikan sesuatu berdasarkan khayalan mereka. Salahsatu yang dikembangkan adalah dengan memberikan pendidikan karakter melalui bercerita atau story telling. Storytelling atau mendongeng adalah bisa menjadi sebuah seni yang menarik. Melalui metode bercerita anak-anak mendapatkan budaya dan pengetahuan baru yang berbeda dan akan sangat mudah untuk memasukkan nilai-nilai yang baik bagi mereka. Anak-anak akan menjelajahi dunia baru dan melibatkan mereka dalam visualisasi plot dan karakter.

Metode bercerita dapat mempermudah pesan disampaikan kepada anak anak usia dini atau usia taman kanak kanak. Dengan story telling anak anak lebih mudah memahami sesuatu dan menyerap hal-hal yang positif dengan suasana yang menyenangkan. Bercerita dijadikan metode untuk menyampaikan nilai-nilai karena dalam cerita dapat ditanamkan nilai moral, nilai agama, nilai sosial, nilai budaya dan sebagainya (Zubaidi, 2017:38-39). Sebenarnya pendidikan karakter berawal dari pendidikan informal di lingkungan keluarga dan masyarakat, karena pendidikan formal di sekolah hanyalah sepertiga dari seluruh waktu anak bersosialisasi dengan lingkungannya (Fitri, 2012).

Sebenarnya pendidikan karakter berawal dari pendidikan informal di lingkungan keluarga dan masyarakat, karena pendidikan formal di sekolah hanyalah sepertiga dari seluruh waktu anak bersosialisasi dengan lingkungannya . Dengan demikian sekolah diharapkan dapat menjadi tempat dini bagi penanaman karakter - karakter yang baik bagi anak -anak. Sejak kecil, anak-anak harus 
dapat memahami benar karakter-karakter yang baik agar ketika dewasa karakter-karakter yang baik itu sudah ada di dalam diri mereka. Demikian pula, pentingnya pendidikan karakter di sekolahsekolah disebabkan karena karakter merupakan masalah pokok dalam pembangunan sebuah bangsa sehingga bangsa itu menjadi bangsa yang teguh dan karakter perlu dibentuk dan dibangun bukan otomatis datang dengan sendirinya (Sulistyowati, 2012).

Dengan demikian sekolah diharapkan dapat menjadi tempat dini bagi penanaman karakter - karakter yang baik bagi anak -anak. Sejak kecil, anak-anak harus dapat memahami benar karakter-karakter yang baik agar ketika dewasa karakter-karakter yang baik itu sudah ada di dalam diri mereka. Secara sederhana, pendidikan karakter dapat didefinisikan sebagai segala usaha yang dapat dilakukan untuk mempengaruhi karakter siswa. Program storytelling adalah media tepat untuk memenuhi kebutuhan tersebut karena dalam cerita terdapat nilai-nilai yang dapat dikembangkan (Siswanto. 2008).

Dengan penggunaan strategi storytelling di taman kanak-kanak perlu diperhatikan hal-hal sebagai berikut: 1) Isi cerita harus terkait dengan dunia kehidupan anak TK, sehingga mereka lebih dapat memahami dan menangkap isi cerita tersebut. Dengan kata lain, apa yang dibahas tidaklah asing bagi mereka. 2) Kegiatan bercerita harus dapat memberikan perasaan gembira, lucu, dan mengasyikkan sesuai dengan dunia kehidupan anak yang penuh suka cita. 3) Kegiatan bercerita harus menjadi pengalaman bagi anak-anak TK yang bersifat unik dan menarik, menggetarkan perasaan anak, serta dapat memotivasi anak untuk mengikuti cerita tersebut sampai tuntas strategi storytelling atau strategi bercerita merupakan salah satu strategi pembelajaran yang dapat memberikan pengalaman belajar bagi anak Taman Kanak-kanak. Metode bercerita dalam konteks ini dapat menjadi alat efektif untuk meningkatkan moral judgement antara diri anak dan orang lain. Moral judgement merupakan manifestasi untuk membuat kesimpulan atau keputusan tentang sesuatu, baik yang berkaitan dengan berbagai dilema dalam kehidupan nantinya yang mampu membantu anak-anak menjadi positif (Zubaidi, 2017: 39). Hal positif lain yang nantinya diperoleh, merujuk pada Miller and Pennycuff (2008: 36) yaitu using storytelling in the classroom is one way to address literacy development by improving oral language, reading comprehension, and writing. Because of the interrelated nature of the processes involved in reading and writing, storytelling is an effective pedagogical strategy that can be woven into instruction to increase students' competencies in all areas. Yaitu praktik mendongeng di kelas adalah salah satu cara untuk mengatasi perkembangan literasi dengan meningkatkan bahasa lisan, pemahaman membaca, dan menulis. Karena sifat saling terkait dari proses yang terlibat dalam membaca dan menulis, mendongeng adalah strategi pedagogis yang efektif yang dapat ditemui menjadi instruksi untuk meningkatkan kompetensi siswa di semua bidang.

Taman Kanak kanak An-Nizomiyah Pejaten adalah salahsatu sekolah TK Swasta yang terletak di Provinsi DKI Jakarta, Jakarta Selatan yang cukup dikenal oleh masyarakat. Sekolah ini beralamat di Jl. Al Fajri No.16, RT.12/RW.1, Pejaten Barat, Kecamatan. Pasar Minggu, Kota Jakarta Selatan, Daerah Khusus Ibukota Jakarta 12510. Sekolah ini menggunakan Agama Islam sebagai pegangan utama Pendidikan Agamanya, sehingga kegiatan pengabdian yang bertema storytelling ini sangat membantu para guru untuk memperluas wawasan anak-anak mengenai karakter-karakter baik untuk mendukung guru dalam pencapaian pembelajaran. Karena kondisi pembelajaran yang dilakukan di TK terasa monoton sehingga dengan kegiatan ini anak-anak menjadi bergairah dan tidak merasa bosan dengan teknik pembelajaran yang biasanya hanya diperoleh guru mereka saja. Maka dengan tim dosen dan mahasiswa Universitas Nasional bersinergi untuk melakukan pengabdian masyarakat di TK tersebut.

\section{METODE}

Dalam Storytelling ini perlu dilakukan perencanaan dalam penggunaan metode. Ada beberapa metode dalam Storytelling antara lain: menggunakan boneka, benda visual, metode sandiwara, metode bercakap-cakap, metode bermain peran dan metode tanya jawab (Tampubolon, (1991 : 18). Dalam kegiatan pengabdian masyarakat ini menggunakan metode bermain peran dan metode tanya jawab.

Sebelum acara storytelling dimulai, tim pengabdi telah mempersiapkan terlebih dahulu jenis cerita yang akan disampaikan. Cerita dikisahkan dengan melalui cerita drama. Program 
pengabdian masyarakat ini dibagi dalam dua sesi yaitu sesi pertama dengan menampilkan cerita mengenai binatang yang bertema "Penggembala dan Biri-biri" yang dimainkan oleh para mahasiswa Universitas Nasional Jakarta. Sesi kedua, adalah anak-anak diminta mengulang dan menyebutkan karakter-karakter baik dan buruk di dalam rangkaian cerita yang ada dan anak anak diminta mencari solusi mana yang baik dan harus bagaimana seharusnya. Dalam hal ini diupayakan anak-anak untuk tumbuh daya kritis dan imaginatif positif yang tumbuh dari anakanak.

Kegiatan di mulai pukul 8.00 pagi sampai siang hari dengan kegiatan cerita drama atau bermain peran yang dimainkan oleh para mahasiswa Universitas Nasional, didampingi Tim Pengabdi, serta didukung properti hasil karya para mahasiswa Universitas Nasional, kemudian meminta anak-anak TK untuk menceritakan kembali, menyampaikan pendapatnya tentang tema serta menyebutkan karakter-karakter yang terdapat dalam cerita dan disuruh bercerita pengalaman yang pernah di alami yang mencerminkan karakter-karakter yang diperoleh tersebut. Para pelaksana Kegiatan Pengabdian ini memposisikan diri sebagai mediator para pihak yang terkait dan bersama-sama menyelesaikan masalah yang ada yang ditemui apabila ada kesulitan misalnya menemukan karakter baik atau buruk dalam cerita.

\section{HASIL DAN PEMBAHASAN}

Sebelum sampai pada Hasil dan Pembahasan, mak dijelaskan terlebih dahulu sinopsis cerita peran yang di mainkan ini mengadopsi cerita drama dalam kisah Ipin Upin. Yaitu sebagai berikut: Jarjit menjadi seorang pengembala biri-biri, Upin dan Ipin menjadi seorang petani, Mail menjadi seekor serigala. Suatu saat Jarjit merasa bosan dengan pekerjan yang hanya mengembala, oleh karena itu dia ingin mencari sedikit hiburan, tidak berapa lama datanglah dua orang petani yaitu Upin dan Ipin. Sang pengembala tersebut berteriak berpura-berpura seolah-olah biri-birinya dimakan oleh serigala. Akhirnya kedua petani (Upin-Ipin) tersebut sontak langsung menghampirinya dan berniat memberi bantuan. Akan tetapi sesampainya petani tersebut dihadapan pengembala, pengembala tersebut malah ketawa dan merasa puas telah mengerjai kedua petani tersebut. Hal tersebut diulang-ulang oleh pengembala itu, hingga pada kejadian yang ketiga pengembala berteriak-teriak meminta pertolongan seperti halnya kejadian yang pertama dan kedua, akan tetapi kedua petani tersebut tidak mau menolong karena merasa sudah di tipu dua kali. Teriakan pengembala yang ketiga kalinya tidaklah dibuat-buat, karena biri-biri sang pengembala memang telah dimakan oleh seekor serigala. Setelah kejadian itu kedua petani (Upin dan Ipin) mendatangi sang pengembala (Jarjit), dan mengatakan: "itulah akibat yang akan kamu terima sang pengembala, ketika kamu berkata bohong pada seseorang maka selamanya kamu tidak akan dipercaya oleh orang lain, meskipun engkau berkata jujur sekalipun".

Hasil dari kegiatan cerita ini dapat meningkatkan kemampuan mengingat dan juga semakin melatih komunikasi lisan dengan suasana alamiah ketik anak-anak diminta untuk menceritakan kembali dari hasil pengamatan terhadap cerita drama yang di mainkan kakak-kakak mahasiswa Universitas Nasional. Di samping itu anak-anak memiliki kemampuan mendengarkan. Anak-anak TK merasa seperti bermain. Kemampuan berkomunikasi sangat penting bagi anak usia taman kanak-kanak sesuai dengan tingkat perkembangannya, hal ini sangat berguna sekali agar dalam berkomunikasi dengan orang lain baik dengan anak-anak yang lain maupun dengan orang dewasa dapat dipahami. Kemampuan mengajukan pertanyaan meningkat karena anak-anak memperoleh berbagai pengalaman dan kesempatan baru yang menstimulasi rasa ingin tahu mereka. Pertanyaan yang diajukan anak lebih banyak menggunakan kalimat tanya apa, siapa dan mengapa sehingga bisa memacu untuk bertanya lebih jauh dan mendalam. 


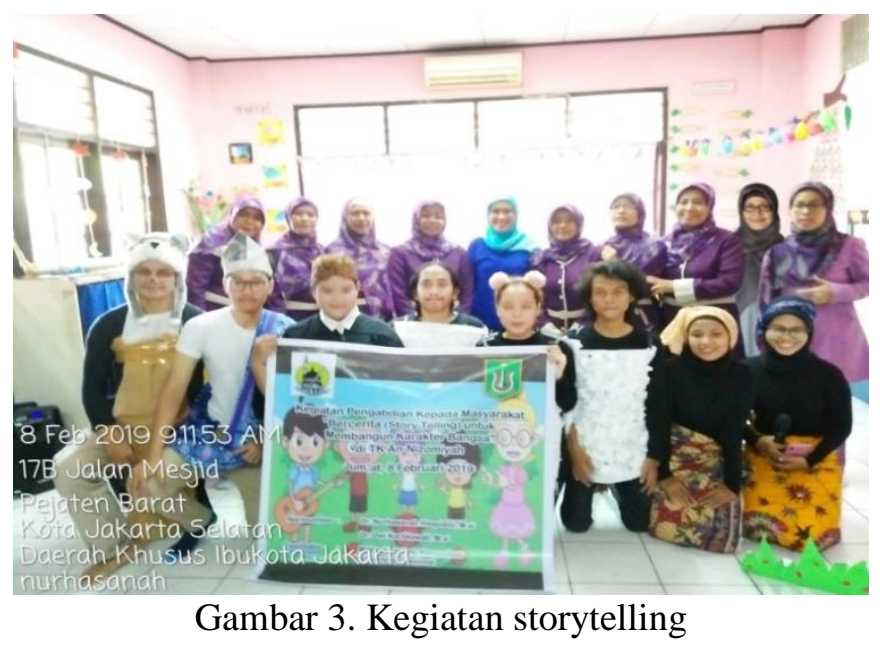

Hasil kegiatan ini menjadikan anak-anak TK mendapatkan pengetahuan mengenai nilainilai karakter yang baik dan dapat menyebutkan nilai-nilai yang buruk dari cerita dalam peran tersebut. Penggunaan properti pada metode bermain peran tentang storytelling ini semakin membuat anak-anak antuasias mengikuti acara dari awal hingga akhir.

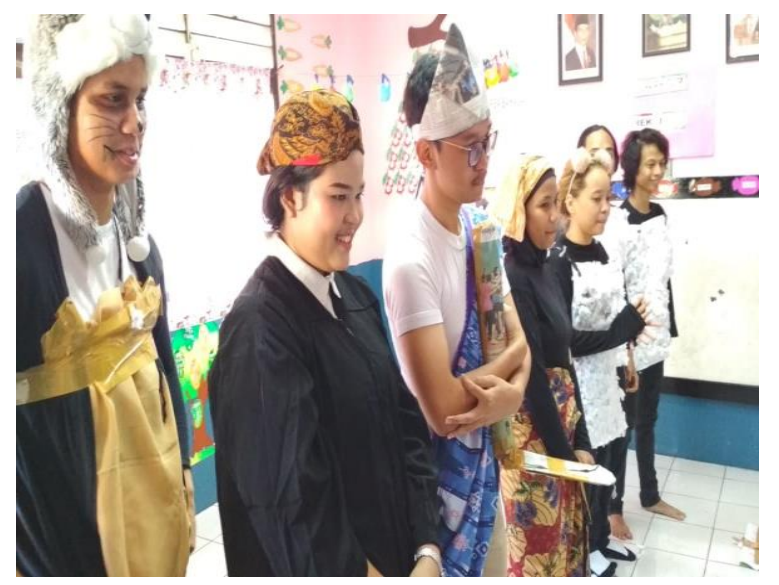

Gambar 2. Berbagai peran yang dimainkan

Kegiatan ini dilaksanakan dengan tujuan untuk membuat anak-anak usia taman kanakkanak tertarik dan memahami nilai-nilai karakter bangsa. Data-data yang dikumpulkan selama pelaksanaan kegiatan ini, walaupun terbatas, menunjukkan hasil yang positif karena menunjukkan bahwa semua peserta menyukai kegiatan ini. Mereka serius menonton hingga tuntas dan mendengarkan cerita tersebut. Menurut Lindsay (2015: 11) mengatakan:" Only five percent of students remembered the stats, but a whole 63\% remembered the story", artinya lima persen saja anak-anak mengingat statistik, tetapi sebanyak 63 persen anak-anak mengingat cerita.

Pelaksanaan kegiatan pengabdian ini masih sangat terbatas karena dilaksanakan hanya di satu sekolah. Diharapkan ke depan nantinya bisa dilakukan kegiatan serupa yang sangat bermanfaat untuk mendukung kebijakan sekolah dalam penanaman nilai-nilai karakter yang baik bagi anak anak usia taman kanak kanak melalui medium cerita. Keterampilan sosial anak yang semakin meningkat meliputi bersosialisasi di lingkungan bermain katika memiliki teman baru, menambah kosakata, mengikuti aturan permainan, dan mengatasi konflik yang terjadi dengan teman sebayanya. Cerita dikembangkan dengan memodifikasi tema dan cerita dalam permainan sehingga lebih bisa mengeksplor kemampuan anak. Selain itu metode bermain peran dapat melibatkan subjek pelatihan dengan usia yang bervariasi sehingga dapat melihat perbedaan keterampilan sosial pada tiap tahap usia. Mereka semangat sekali mendengarkannya. Serta di akhir dongeng, saat ditanyakan kembali tentang ceritanya mereka pun hafal dan bisa menjawabnya. 


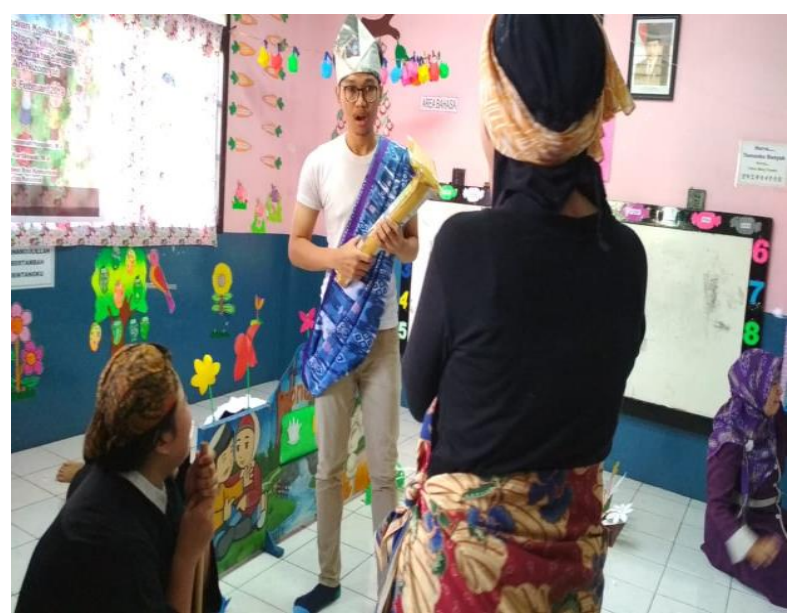

Gambar 3. Berbagai Peran yang menunjukkan karakter bangsa

Hasil yang dicapai dari cerita sebagai medium atau alat transfer nilai-nilai nilai-nilai karakter antara lain:

- Karakter Toleransi

Anak-anak dapat memahami bahwa dalam kehidupan harus ada toleransi. Manfaat dari pemahaman nilai-nilai toleransi ini antara lain dengan mengajarkan toleransi lebih cepat akan lebih baik bagi perkembangan jiwa anak-anak taman kanak-kanak ini. Karena terkadang di saat anak mulai bergaul dengan teman-temannya, sifat keakuan anak akan muncul. Jika tidak diajarkan bertoleransi, maka konflik dengan teman bermainnya karena perbedaan, akan sangat mungkin terjadi. sedangkan apabil tidak ada toleransi maka dapat menimbulkan perpecahan dan konflik yang pada akhirnya justru berefek buruk pada diri sendiri.

- Karakter Jujur

Dalam kehidupan kita harus jujur karena kalau kita suka berbohong pada orang lain, karena jika sering berbohong maka orang lain akan menjadi tidak percaya dengan perkataan kita. Ini seperti yang ada dalam cerita di mana penggembala tidak ada yang menolong akibat dari perbuatan sebelumnya yang suka berbohong. Secara tidak langsung dengan kegiatan pengabdian ini mengajarkan kejujuran, yang merupakan perilaku untuk menjadikan dirinya sebagai orang yang selalu dapat dipercaya dalam perkataan, tindakan dan pekerjaan. Menanamkan sikap jujur pada anak bukanlah yang mudah, kita perlu berhati-hati dalam memberikan contoh pada mereka. Karakter ini adalah karakter yang paling menonjol muncul dalam storytelling ini. Hampir seluruh peserta anak anak TK ini mampu merespon dengan baik sehingga sampai berebut menjawabnya. Bahkan anak-anak mampu menjelasakan apabila suatu saat nanti tidak jujur maka akan berefek buruk bagi diri sendiri. Menurut mereka walaupun tidak ada yang melihat namun Tuhan YME tetap melihatnya, maka harus jujur.

- Karakter Bersahabat/komunikatif,

Dalam kehidupan harus saling bersahabat dan tolong menolong supaya kalau suatu saat kita membutuhkan maka orang lain akan membantu kita lagi. Jangan malah membohongi. Dengan karakter bersahabat maka ia akan dapat menyesuaikan diri dalam segala situasi, disukai orang, menghargai perbedaan, peka terhadap masalah sosial dan mampu mengurangi perilaku negatif yang mungkin timbul. Anak-anak mespon dengan baik tipe karakter ini, mereka mampu menjelaskan akibat yang ditimbulkan apabila mereka menjadi anak yang tidak bersahabat maka dia akan dikucilkan dan teman-temannya akan malas menolong dan lain-lain.

- Karakter Peduli Sosial 
Rasa kepekaan sosial, harus ditanamkan pada diri seorag anak terutama di usia Taman kanak-kanak supaya dia dapat belajar dari apa yang ia lihat, ia dengar dari sekitarnya, dan juga yang ia rasakan. Nantinya anak akan bisa mampu memahami masalah yang dihadapinya dan mampu mencari jalan keluarnya. Anak yang memiliki kepekaan sosial yang baik maka dia juga cenderung aktif dalam memberi bantuan kepada orang yang membutuhkan. Pada karakter ini, anak anak agak mengalami kesulitan dalam memahami peduli sosial, walaupun mereka paham ketika suatu saat nanti ada yang meminta bantuan maka mereka harus bagaimana, disitulah sebenarnya di asah rasa peka terhadap orag lain.

- Karakter Cinta Damai

Rasa cinta damai akan tumbuh di jiwa anak-anak usia TK ini sehingga mereka dapat menghilangkan rasa kebencian pada orang lain. Dia akan menghormati orang yang ada disekitarnya tanpa melihat perbedaan yang ada.

- Rasa ingin tahu

Dengan ditumbuhkan rasa ingin tahu maka, seorang anak akan dapat bereaksi terhadap lingkungannya dengan cara yang positif. Terkadang anak akan menemui sesuatu yang asing dan tidak pantas dari lingkungan, maka dia akan mengobservasi secara hati-hati dan tidak gegabah. Dari awal cerita anak-anak sangat antusias mengikuti kegiatan ini dikarenakan memang karena ada rasa penasaran terhadap jalan cerita yang ada.

- Karakter Tanggung jawab.

Apabila kita berbuat maka disitulah kita akan menuai. Artinya apabila kita melakukan perbuatan tertentu maka kita harus bertanggungjawab untuk menerima akibatnya. Sikap bertanggung jawab memungkinkan seseorang untuk bisa menyelesaikan tugasnya dengan baik dan berusaha tidak menyulitkan orang lain. Anak-anak juga agak sulit sebenarnya menemukan karakter ini, akan tetapi dengan dibantu dijelaskan oleh para pengabdi maka anak-anak mampu memahami dan memberi contoh penerapan dalam kehidupan sehari-hari misalnya kalau tidak bertanggungjawab terhadap tugas misalnya maka dia akan mendapatkan sanksi, dan lain-lain.

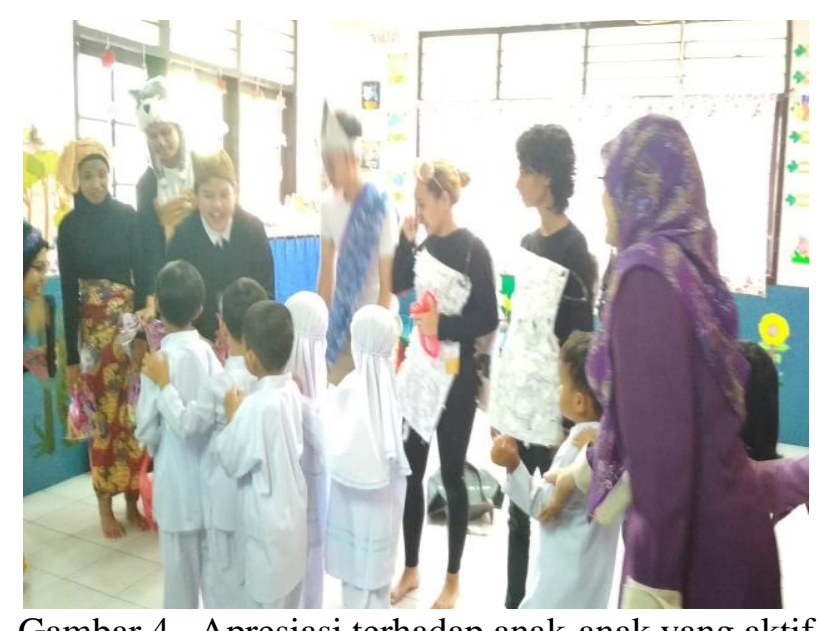

Gambar 4. Apresiasi terhadap anak-anak yang aktif 


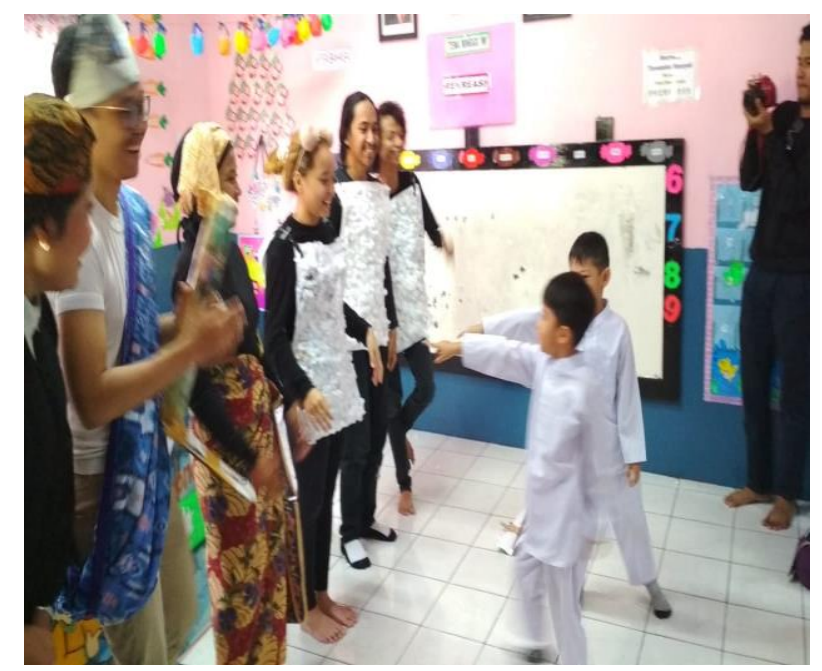

Gambar 4. Anak-anak yang aktif menyebutkan karakter bangsa yang muncul

Faktor utama yang mendukung keberhasilan cerita atau story telling dalam membentuk karakter harus diulang-ulang, dengan dorongan kerjasama dengan guru dan anak-anak. Sementara faktor penghambat keberhasilan storytelling adalah anak-anak yang cepat lelah dan bosan sehingga sangat diperlukan teknik yang kreatif dan menarik untuk menghadapi anak-anak dalam pembentukan karakter ini. Dari hasil pengabdian ini sangat berguna dalam mengembangkan daya pikir anak-anak yang memiliki kemampuan mengingat dan berimaginasi. Selain itu dapat mengembangkan kemampuan untuk berani bertanya dan berbicara dalam merespon kegiatan ini. Terakhir yang paling penting dapat mengembangkan nilai-nilai karakter positif di usia dini.

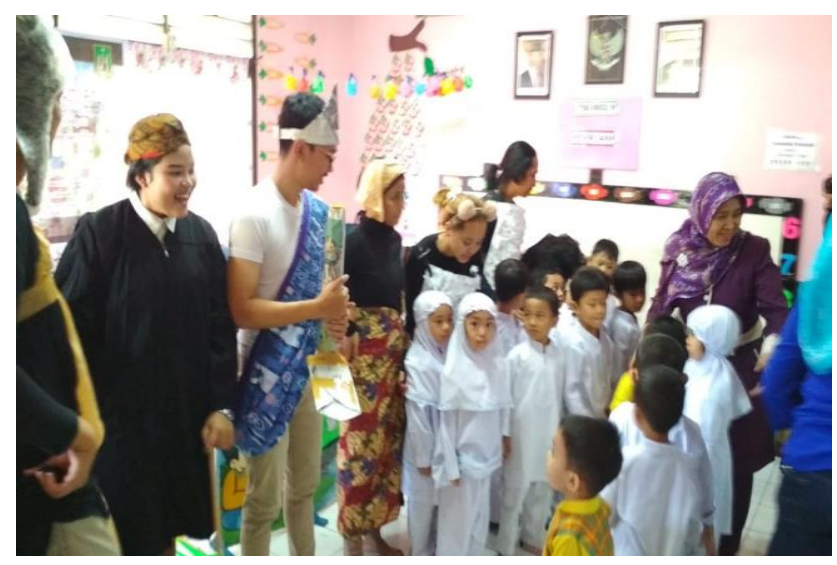

Gambar 5. Anak-anak antri merespon dengan menjawab berbagai karakter yang ada dalam cerita

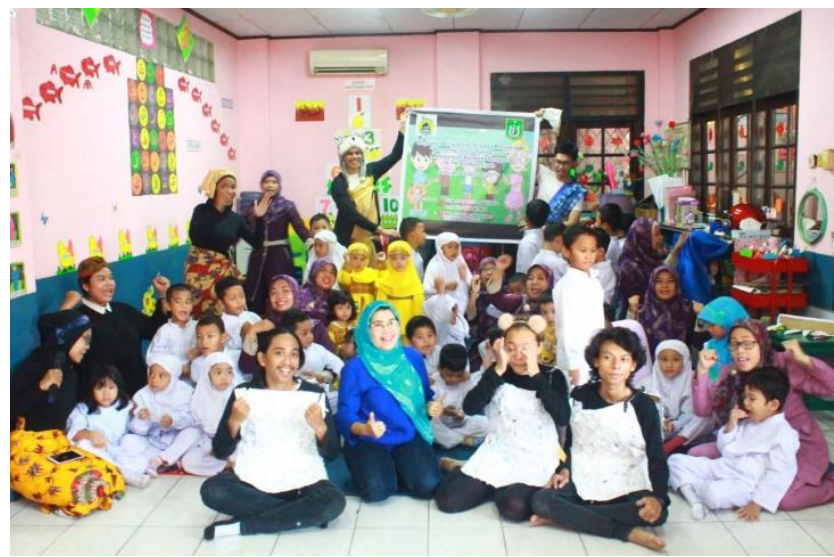

Gambar 6. Seluruh peserta dan pemain serta para pengabdi 


\section{KESIMPULAN}

Program pengabdian pada masyarakat dapat dilaksanakan dan direspon dengan oleh kepala sekolah, guru-guru di Sekolah TK ini dan sesuai dengan tujuan untuk membuat anak-anak usia taman kanak-kanak tertarik dan memahami nilai-nilai karakter bangsa dengan menggunakan metode cerita atau story telling. Hasil menunjukkan bahwa kegiatan ini menjadi media transfer ilmu pengetahuan terutama dalam menanamkan nilai-nilai karakter dan menjadi alat efektif untuk meningkatkan moral judgement mereka dalam suasana yang menyenangkan. Semua peserta menyukai kegiatan storytelling dan mendengarkan storytelling yang dibawakan oleh tim pengabdi dan para mahasiswa. Pelaksanaan kegiatan pengabdian ini masih sangat terbatas karena dilaksanakan hanya di satu sekolah. Diharapkan ke depan nantinya bisa dilakukan kegiatan serupa yang sangat bermanfaat untuk mendukung kebijakan sekolah dalam penanaman nilai-nilai karakter yang baik bagi anak anak usia taman kanak kanak

\section{SARAN}

Untuk evaluasi kegiatan berikutnya, perlu penguatan dan penyususnan program yang berkesinambungan seiring dengan perlu dilakukan kegiatan semacam ini secara rutin. Evaluasi hasil kegiatan dilakukan dengan lebih banyak lagi mengukur kemampuan anak dalam penguasaan cerita dengan dilakukan secara berulang, karena dengan demikian hasil kegiatan memperlihatkan hasil positif, karena anak anak menjadi terasah kemampuan memori ingatan dan juga memiliki wawasan kreatif. pembelajaran nilai-nilai yang baik bagi tumbuh kembang pembelajaran karakter pada anak-anak. Untuk kegiatan serupa perlu adanya partisipasi mahasiswa dan dosen sebagai fasilitator yang lebih banyak, dan sekolah-sekolah yang lebih variatif sehingga semakin banyak pengalaman positif yang dapat dibagikan kepada anak-anak terutama anak anak usia sekolah kanak-kanak sebagai dasar pembentukan konsep diri positif dalam pembentukan karakter.

\section{UCAPAN TERIMA KASIH}

Penulis mengucapkan terima kasih kepada Ketua LPPM Universitas Nasional Jakarta Prof. Dr. Ernawati Sinaga, M.S., Apt berikut jajarannya yang telah memberi dukungan moril dan finansial terhadap pengabdian ini sehingga dapat terselenggara dengan baik dan lancar.

\section{DAFTAR PUSTAKA}

[1] Salahuddin, A; \& Alkrienciehie, I. (2013). Pendidikan Karakter. Bandung: CV. Pustaka Setia

[2] Kementerian Pendidikan Nasional. (2011). Pedoman Pelaksanaan Pendidikan Karakter. Jakarta: Puskurbuk

[3] Amini, M. (2014). Hakikat Anak Usia Dini. Perkembangan Dan Konsep Dasar Pengembangan Anak Usia Dini, 65. Retrieved from repository.ut.ac.id/4697/1/PAUD4107-M1.pdf

[4] Dikdasmen. (2009). Surat Edaran Mandikdasmen Depdiknas Nomor 1839/C.C2/TU/2009,n.d.Perihal: Penyelenggaraan Pendidikan Taman Kanak-Kanak dan Penerimaan Siswa Baru Sekolah Dasar

[5] Khasinah, S. (2015). Interaksi Ekstratekstual dalam Proses Bercerita kepada Anak Usia Dini. Gender Equality: International Journal of Child and Gender Studies. https://doi.org/10.22646/jcgs.v1i1.782

[6] Zubaedi. (2017). Strategi Taktis Pendidikan Karakter (Untuk PAUD dan Sekolah). Depok: Radja Grafindo Persada 
[7] Fitri, AZ. (2012). Reinventing human character: Pendidikan karakter berbasis nilai dan etika di sekolah. Yogyakarta: Ar-Ruzz Media

[8] Sulistyowati, E. (2012). Implementasi Kurikulum Pendidikan Karakter. Yogyakarta: PT Citra Aji Parama

[9] Siswanto, I. (2008). Mendidik Anak Dengan Permainan Kreatif: Bermain Sambil Belajar Untuk Mengembangkan Kecerdasan Majemuk Sejak Usia Dini.Yogyakarta: ANDI

[10] Miller, S., \& Pennycuff, L. (2008). The Power of Story: Using Storytelling to Improve Literacy Learning. 1(1), 36-43.

[11] Tampubolon. (1991). Mengembangkan Minat dan Kebiasaan Membaca pada Anak. Bandung: Angkasa

[12] Lindsay, F. (2015). The Seven Pillars of Storytelling. Sparkol Books. Bristol UK 